G

OPEN ACCESS

Citation: Botero JE, Posada-López A, Mejía-Vallejo J, Pineda-Tamayo RA, Bedoya-Giraldo E. Effects of nonsurgical periodontal therapy in patients with rheumatoid arthritis: a prospective before and after study. Colomb Méd (Cali), 2021; 52(3):e2095051 http://doi. org/10.25100/cm.v52i 3.5051

Received: 26 Jun 2020

Revised: 09 Aug 2021

Accepted : 14 Sep 2021

Published: 30 Sep 2021

Keywords:

Rheumatoid arthritis; periodontitis; C-reactive protein; rheumatoid factor; anti-citrullinated protein antibodies; periodontal debridement; dysbiosis

Palabras clave:

Artritis reumatoide; periodontitis; proteína $\mathrm{C}$ reactiva; factor reumatoide; anticuerpos anti-proteína citrulinada; debridamiento periodontal; disbiosis

Copyright: @ 2021 Universidad del Valle (c) (1) 8
ORIGINAL ARTICLE

\section{Effects of nonsurgical periodontal therapy in patients with rheumatoid arthritis: a prospective before and after study}

\section{Efectos de la terapia periodontal no quirúrgica en pacientes con artritis reumatoide: estudio prospectivo de antes y después}

\author{
Javier Enrique Bntero, ${ }^{1}$ Adriana Posada-Lónez, ${ }^{1}$ Jimi Mejía-Vallejo, ${ }^{2}$ Ricardo Antonio \\ Pineda-Tamayo, ${ }^{2}$ Emilio Bedoya-Giraldo' ${ }^{1}$ (D) \\ drjavo@yahoo.com
}

1 Universidad de Antioquia, Facultad de Odontología, Medellín-Colombia., 2 Artmédica, IPS, Grupo de información clínica, Medellín-Colombia.

\section{Abstract}

\section{Background:}

Periodontal therapy has been suggested to have systemic effects. However, studies of periodontal therapy in rheumatoid arthritis patients have produced controversial results.

Aim:

To compare the effects of nonsurgical periodontal therapy on biochemical markers of rheumatoid arthritis and periodontal parameters in patients with and without rheumatoid arthritis.

\section{Methods:}

A prospective before-and-after study was conducted that included 21 participants without and 29 participants with rheumatoid arthritis. Periodontal parameters, Porphyromonas gingivalis detection, C-reactive protein, rheumatoid factor and anti-citrullinated protein antibodies were measured at baseline and three months after nonsurgical periodontal therapy and the changes were statistically assessed.

\section{Results:}

Groups presented statistically significant improvement in periodontal parameters $(p<0.05)$. There was an increase in the counts of $P$. gingivalis in both groups at three months. In addition, there was a reduction in levels of anti-citrullinated protein antibodies and rheumatoid factor in participants with rheumatoid arthritis. In contrast, C-reactive protein levels increased in both groups but were higher in the rheumatoid arthritis group. Periodontal parameters in rheumatoid arthritis participants under diseasemodifying antirheumatic drugs presented a slightly higher improvement $(p<0.05)$.

\section{Conclusions:}

Nonsurgical periodontal therapy has similar improvements in periodontal parameters in patients with and without rheumatoid arthritis. In addition, nonsurgical periodontal therapy may benefit serum levels of anti-citrullinated protein antibodies and rheumatoid factors in patients with rheumatoid arthritis. NCT04658615. 
Conflicts of interest:

Authors declared that they have no conflict of interests.

\section{Acknowledgements:}

Dentaid-Colombia kindly donated oral health packs. The authors are grateful to the patients and personnel at Artmédica-IPS who participated in this study.

\section{Funding:}

This study was funded by a grant (CODI 2015-6263) from the

Universidad de Antioquia

\section{Corresponding author:}

Javier Enrique Botero. Facultad de Odontología, Universidad de Antioquia, Calle 70\# 52-21, Medellín, Colombia

E-mail: drjavo@yahoo.com

\section{Resumen}

\section{Antecedentes:}

Se ha sugerido que la terapia periodontal tiene efectos sistémicos. Sin embargo, los estudios de la terapia periodontal en pacientes con artritis reumatoide han producido resultados controvertidos.

\section{Objetivo:}

Comparar los efectos de la terapia periodontal no quirúrgica sobre los marcadores bioquímicos de la artritis reumatoide y los parámetros periodontales en pacientes con y $\sin$ artritis reumatoide. 0.3 se realizó un estudio prospectivo de antes y después que incluyó a 21 participantes sin artritis reumatoide y 29 participantes con artritis reumatoide. Se midieron los parámetros periodontales, detección de Porphyromonas gingivalis, proteína $\mathrm{C}$ reactiva, factor reumatoide y anticuerpos anti-proteína citrulinada al inicio del estudio y tres meses después de la terapia periodontal no quirúrgica y los cambios se evaluaron estadísticamente.

\section{Resultados:}

En general, ambos grupos presentaron mejoría estadísticamente significativa en los parámetros periodontales $(p<0.05)$. Hubo un aumento en los recuentos de $P$. gingivalis en ambos grupos a los tres meses. Además, hubo una reducción en los niveles de anticuerpos anti-proteína citrulinada y factor reumatoide en participantes con artritis reumatoide. Por el contrario, los niveles de proteína C reactiva aumentaron en ambos grupos, pero fueron más altos en el grupo de artritis reumatoide. Los parámetros periodontales en los participantes con artritis reumatoide bajo fármacos antirreumáticos modificadores de la enfermedad presentaron una mejoría ligeramente mayor $(p<0.05)$.

\section{Conclusiones:}

La terapia periodontal no quirúrgica tiene mejoras similares en los parámetros periodontales en pacientes con y sin artritis reumatoide. Además, la terapia periodontal no quirúrgica puede beneficiar los niveles séricos de anticuerpos anti-proteína citrulinada y factor reumatoide en pacientes con artritis reumatoide. NCT04658615.

\section{Remark}

\section{1) Why was this study conducted?}

It has been suggested that periodontitis and rheumatoid arthritis are bi-directional and that periodontal therapy has systemic effects. Therefore, this study was carried out to compare the effects of periodontal therapy on biochemical and clinical parameters in patients with and without rheumatoid arthritis.

\section{2) What were the most relevant results of the study?}

Periodontal parameters improved regardless of the systemic condition. However, there was a reduction in levels of anti-citrullinated protein antibodies and rheumatoid factor in participants with rheumatoid arthritis after periodontal treatment.

\section{3) What do these results contribute?}

Periodontal therapy may positively affect serum levels of anti-citrullinated protein antibodies and rheumatoid factor in patients with rheumatoid arthritis and consequently help improve their disease activity. 


\section{Introduction}

Periodontitis and rheumatoid arthritis (RA) are inflammatory diseases that lead to connective tissues and bone destruction. The prevalence of severe periodontitis globally has been estimated at around $11 \%$ but with the additional sum of moderate and slight periodontitis, the prevalence could rise to nearly $50 \%^{1,2}$. In Colombia, around $60 \%$ of the population has periodontitis ${ }^{3}$. In contrast, recent data indicate that the global prevalence of RA is between $0.40-1 \%$, with a similar prevalence in Colombia $(0.52 \%)^{4,5}$. Both diseases are of great interest as they have been found to impact the quality of life of people negatively ${ }^{6,7}$. In the last decade, evidence has emerged suggesting an association between the two conditions ${ }^{8-10}$.

While periodontitis has a strong microbial etiology, RA results from an autoimmune response. The accumulation of a dysbiotic biofilm around teeth leads to the inflammation of gingival tissues that, without proper control, continue to develop periodontitis in which periodontal attachment tissues and tooth surrounding bone are resorbed. On the other hand, RA results from an accumulation of an autoimmune inflammatory infiltrate in the synovial membrane leading to the continuous destruction of connective and bone tissues of the joints. The etiology of RA is unknown but genetic, environmental factors and smoking have been recognized as significant risk factors, and more recently, dysbiosis of the gut microbiome has been associated as a contributing factor for autoimmune diseases including RA ${ }^{11-13}$. In addition, RA affects the joints and contributes to chronic systemic inflammation and, therefore, compromises multiple organs and tissues in the body ${ }^{14}$.

Studies have suggested that both conditions share some pathogenic mechanisms. They are characterized by the increased local production of matrix metalloproteinases (MMPS) and proinflammatory cytokines such as IL-1, TNFa, IL-6 and IL-17, which are important inducers of connective tissue and bone resorption. C-reactive protein (CRP), a pentameric protein produced in the liver as a result of chronic inflammation and infection, is elevated in periodontitis and RA ${ }^{12,13,15}$. Dysbiosis, defined as the imbalance in the normal microbial community, is an important feature in periodontitis and studies suggest that it also plays a role in RA contributing to the onset of chronic inflammation ${ }^{11}$. These shared molecular and biological mechanisms create a dysregulated inflammatory reaction responsible for the destruction of connective tissues and bone around teeth and joints.

It has been proposed that periodontitis may contribute to the pathogenic effects of arthritis. The link was established through Porphymonas gingivalis, an important pathogen in the dysbiotic biofilm in periodontitis. P. gingivalis synthesizes a peptidyl arginine deiminase (PAD) that mediates the citrullination of several proteins such as vimentin, fibrin, and $\alpha$-enolase. Citrullinated proteins are recognized by anti-citrullinated protein antibodies (ACPAs), which is a relevant characteristic of RA ${ }^{13,16,17}$. Studies have found that ACPAs are increased in subjects positive for $P$. gingivalis with and without RA ${ }^{18,19}$. However, $P$. gingivalis affects the production of ACPAs and induces NETs (neutrophil extracellular traps), osteoclastogenesis (prostaglandin E2), and Th17 proinflammatory response that, in a consortium, contribute to bone damage and systemic inflammation ${ }^{20}$. Such mechanisms are suspected to act in a bidirectional way, meaning that RA may be a risk factor for periodontitis and vice versa.

Nonsurgical periodontal therapy (NSPT) has been shown to have systemic effects. Gaudilliere et al. ${ }^{21}$, showed that patients with periodontitis have an exaggerated proinflammatory reaction to $P$. gingivalis and a dysfunctional systemic immune response. But more interesting was that the systemic immune dysfunction was temporarily reversed by NSPT ${ }^{21}$. Studies in RA patients suggest that NSPT improves the periodontal and RA condition ${ }^{22}$. Others found no benefit on clinical parameters of RA and the effects of NSPT on biochemical markers of RA remains controversial ${ }^{23,24}$. Also, differences in the clinical response after NSPT in patients with and without RA have not been addressed. Therefore, the objective of this study was to compare the effects of nonsurgical periodontal therapy on biochemical markers of RA and periodontal parameters in patients with and without RA. 


\section{Materials and Methods}

This prospective before-and-after study protocol was reviewed and approved by the institutional review board (Universidad de Antioquia 05-2016) and conducted according to the Declaration of Helsinki of 1975, as revised in 2013. All participants were required to sign an informed consent upon inclusion. Additionally, the study protocol was registered in Clinical Trials (NCT04658615).

\section{Participants and selection criteria}

Patients with and without RA were recruited between march 2019 and march 2020 from the dental clinics of the Universidad de Antioquia and Artmédica, respectively. Individuals were included according to the following criteria: age $\geq 18$ years old; diagnosis of RA according to the American College of Rheumatology with a disease activity score-28 (DAS28-CRP) $\geq 3.2$ and no change in RA medication in the previous 3 months and during the follow-up; at least 15 teeth excluding third molars; interdental sites with loss of periodontal attachment level (PAL) in $\geq 2$ non-adjacent teeth ${ }^{25}$. Patients without RA met the same criteria except for the diagnosis of RA. In addition, individuals were excluded if they reported periodontal treatment or use of antibiotics in the previous three months, diabetes, HIV, liver disease, head and neck radiation therapy, pregnancy, and use of cyclosporine. Smoking, hypertension, and hyperlipidemia medication were not exclusion criteria and were recorded accordingly.

RA participants were under medication, including nonsteroidal anti-inflammatory drugs (NSAIDs), nonbiologic and biologic disease-modifying antirheumatic drugs (DMARDs), and corticosteroids. Non-biologic DMARDs included hydroxychloroquine, methotrexate, sulfasalazine and leflunomide. Biologic DMARDs included Adalimumab, Etanercept, Abatacept, Golimumab, Infliximab, Rituximab and Tocilizumab. No changes in the medication during the follow-up period was performed in order to analyze the effects of periodontal treatment. However, once the follow-up was finalized, the treating doctor adjusted or modified the pharmacological therapy according to each case.

\section{Clinical examination, microbiological and serum samples}

After participants were screened for inclusion, serum samples were collected for the analysis of high-sensitivity C-reactive protein (hs-CRP; $\mathrm{mg} / \mathrm{L}$ ), rheumatoid factor (RF; U/mL) and anti-citrullinated protein antibodies (ACPAs; $\mathrm{U} / \mathrm{mL}$ ) in a reference laboratory. A complete periodontal chart was completed at six sites per tooth excluding third molars by a single experienced clinician using a calibrated probe (UNC-15, Hu-Friedy Mfg. Co.). An experienced rheumatologist examined RA patients to determine their DAS28-CRP score. Subgingival plaque samples were collected and pooled from the 5 most profound periodontal sites. Detection of $P$. gingivalis was immediately performed using culture techniques and expressed as colony-forming units per $\mathrm{mL}(\mathrm{CFU} / \mathrm{mL})$ and frequency detection ${ }^{26}$. All examinations were taken at baseline and repeated three months after the intervention.

\section{Intervention}

Nonsurgical periodontal therapy (NSPT) was administered on the following 5 days of inclusion. A single 1-hour session of full-mouth debridement with an ultrasonic device and curettes was carried out in each participant under local anesthesia by an experienced clinician. After NSPT was completed, each patient received oral hygiene instructions and an oral care pack that included a toothbrush and toothpaste (toothbrush Vitis Encias Medium; Toothpaste Vitis Encias; Dentaid, Colombia).

\section{Outcomes}

The primary outcome was the change in C-reactive protein levels measured as the difference between the baseline and 3-month examination. Secondary outcomes included change in RF and ACPAs as well as change in periodontal attachment level (PAL), probing depth (PD) and bleeding on probing (BOP). 


\section{Data collection}

Demographic, clinical history, as well as medication data for all participants, were collected. Periodontal clinical parameters of PD $(\mathrm{mm}), \mathrm{PAL}(\mathrm{mm})$ and BOP $(\%)$ were recorded at each visit. The stage of periodontitis was established according to the current classification of periodontal diseases ${ }^{25}$. The clinician who recorded data was not blinded to the condition of the patients.

\section{Statistical analyses}

The sample size was calculated to detect a $50 \%$ change in CRP with a power of $>80 \%$ (alpha 0.05 ), resulting in 15 participants per group ${ }^{22}$. Considering possible dropouts, 20 participants were included per group. Randomization was not performed since the purpose was to compare the effects of NSPT in patients with and without RA. The clinical investigator who recorded periodontal parameters was calibrated for repeated measurements before patient inclusion (Kappa value was $\geq 0.80$ for PAL and PD).

A per-protocol analysis was carried to analyze the changes in clinical variables. Categorical variables are presented as frequencies (\%) and analyzed in contingency tables and $X^{2}$. Kolmogorov-Smirnov test was applied to assess for normality. Continuous variables are presented as the mean and 95\% confidence interval (CI). Changes in biochemical markers (CRP, RF, ACPAs) and periodontal parameters (PAL, PD, BOP) are expressed as the delta $(\Delta)$ from baseline to 3 months after the intervention. Differences were determined by the Wilcoxon test for paired and Mann Whitney test for unpaired samples. Considering that the main objective of NSPT is to reduce periodontal inflammation and, in consequence, improve the systemic condition, the outcome of interest was defined as the reduction in biochemical markers of RA. This occurrence was cross-tabulated with the study group type, and the relative risk (RR) was calculated. The level of statistical significance was $5 \%(p \leq 0.05)$.

\section{Results}

The recruitment and demographic description of the study participants are presented in Figure 1 and Table 1. Twenty-one (21) patients without RA and 29 patients with RA with a mean age of 52.3 years old participated in the study. The proportion of female participants was higher in both groups, especially in the RA group $(p=0.04)$. The duration of RA was 11.3 years $(95 \%$ CI: 7.7-14.6). Participants presented similar number teeth, but the stage IV of periodontitis distribution was higher in the group without RA $(p=0.01)$. The distribution of diabetes, hypertension and smoking was not statistically significant between groups. Osteoporosis was more frequent in RA participants.

Changes in periodontal and microbiological parameters at three months after intervention are shown in Table 2 . In general, both groups presented statistically significant improvement in periodontal parameters $(p=0.001)$. Participants without RA had more severe periodontitis than participants with RA, and therefore, the reduction observed at three months in BOP, mean PAL and mean PD was higher than RA participants. However, the relative magnitude (\%) in reduction was similar between groups (15-20\% reduction). There was a more significant increase in the number of sites with PAL 1-2 $\mathrm{mm}$ and $\mathrm{PD} \leq 3 \mathrm{~mm}$, greater reduction in the number of sites with PAL 3-5 $\mathrm{mm}$ and $\geq 5 \mathrm{~mm}$ in the group without RA. There was a greater reduction in the number of sites with $\mathrm{PD} \geq 4 \mathrm{~mm}$ in the group without RA than the RA group. Nonetheless, the relative magnitude (\%) in reduction was greater in the participants with RA than the group without RA ( $42 \%$ vs. $20 \%$ ). The total microbial counts decreased in both groups at 3 months after the intervention. However, there was an increase in the counts and frequency detection of $P$. gingivalis in both groups, but these differences were not statistically significant (Table 2). Participants that were positive for $P$. gingivalis remained positive after NSPT.

Changes in biochemical parameters at three months after intervention are reported in Table 3. There was a mean evident reduction in levels of ACPAs and RF in participants with RA. The 


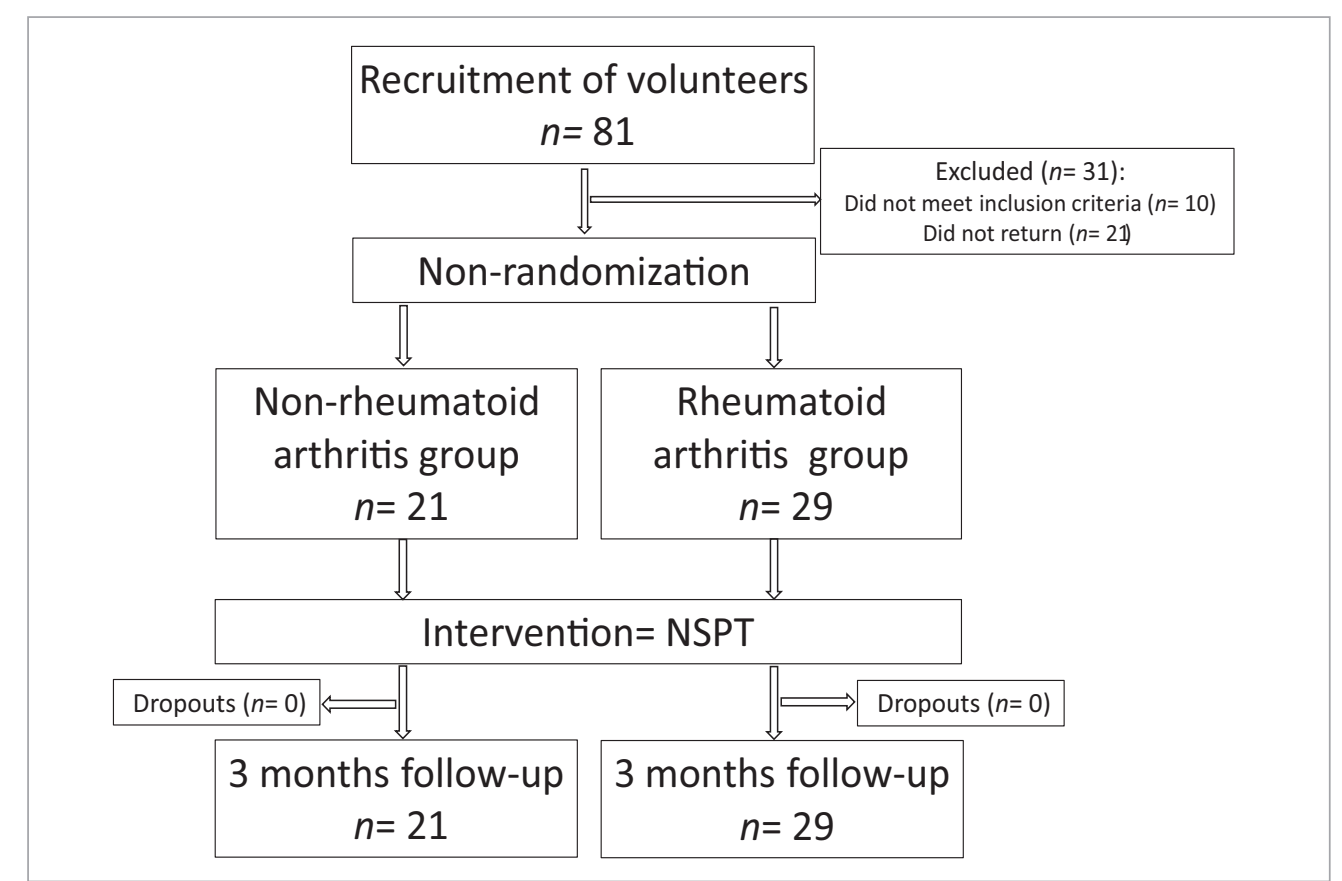

Figure 1. Flowchart of patient inclusion.

levels of RF in patients without RA did not change after NSPT. In contrast, the levels of CRP increased in both groups but were higher in the RA group. This increase's relative magnitude (\%) was similar between groups (20-25\%). The reduction in CRP levels was more likely to occur in patients without RA.

In contrast, the reduction in levels of ACPAs was more likely in patients with RA ( $p=0.003)$. In the same manner, a reduction in levels of RF was more likely in patients with RA $(p=0.001)$ (Table 4). Changes in RF levels in patients without RA were not observed in any patient. This shows that in some patients with RA, NSPT may have beneficial effects on biochemical markers.

Subgroup analysis of RA participants assessed changes in periodontal parameters according to the medication used (Table 5). In general, periodontal parameters in RA participants under DMARD medication presented a slightly higher improvement $(p=0.003)$ except for PD in the non-biologic DMARD group. Nevertheless, these differences were not statistically significant between groups.

Table 1. Demographic description of the study sample

\begin{tabular}{|c|c|c|c|}
\hline Variable & Without RA (n=21) & RA $(n=29)$ & $p^{*}$ \\
\hline \multicolumn{4}{|l|}{ Sex } \\
\hline Male $(\%)$ & $10(47.6 \%)$ & $6(20.7 \%)$ & 0.04 \\
\hline Female (\%) & $11(52.4 \%)$ & $23(79.3 \%)$ & \\
\hline Mean age $(95 \% \mathrm{CI})$ & $52.3(47.2-57.3)$ & $52.3(49.4-55.1)$ & NS \\
\hline 27-59 years old & $17(80.9 \%)$ & $20(68.9 \%)$ & NS \\
\hline$>60$ years old & $4(19.1 \%)$ & $9(31.1 \%)$ & NS \\
\hline RA duration (years); mean (95\% CI) & NA & $11.3(7.7-14.6)$ & NA \\
\hline Number of teeth present & $24.4 \pm 2.9$ & $22.6 \pm 4.4$ & NS \\
\hline \multicolumn{4}{|l|}{ Stage of periodontitis $\mathrm{n}(\%)$} \\
\hline I & 0 & 0 & 0.01 \\
\hline II & 0 & $5(17.2 \%)$ & \\
\hline III & $5(23.8 \%)$ & $16(55.2 \%)$ & \\
\hline IV & $16(76.2 \%)$ & $8(27.6 \%)$ & \\
\hline Diabetes & $0(0)$ & $1(3.4 \%)$ & NS \\
\hline Hypertension & $3(14.3 \%)$ & $10(34.5 \%)$ & NS \\
\hline Osteoporosis & $0(0)$ & $8(27.6 \%)$ & 0.008 \\
\hline Smoking & $0(0)$ & $1(3.4 \%)$ & NS \\
\hline
\end{tabular}

${ }^{*} \mathrm{Ji}^{2}$. NS: not significant; CI: confidence interval; RA: rheumatoid arthritis; NA: not applicable. 
Table 2. Change in periodontal clinical and microbiological parameters from baseline to 3 months.

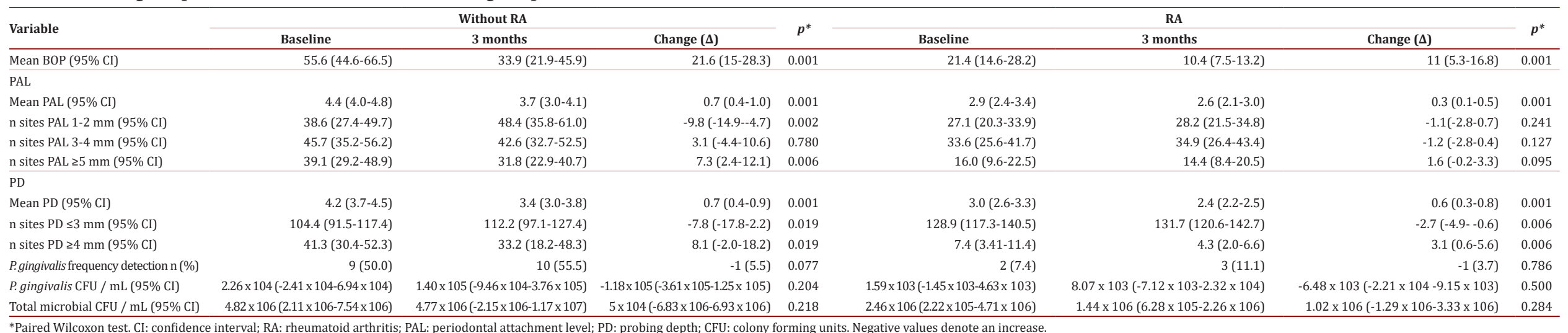


Table 3. Change in biochemical parameters from baseline to 3 months.

\begin{tabular}{|c|c|c|c|c|c|c|c|c|}
\hline \multirow{2}{*}{ Parameter } & \multicolumn{3}{|c|}{ Without RA } & \multirow[b]{2}{*}{$p^{*}$} & \multicolumn{3}{|c|}{ RA } & \multirow[b]{2}{*}{$p^{*}$} \\
\hline & Baseline & 3 months & Change $(\Delta)$ & & Baseline & 3 months & Change $(\Delta)$ & \\
\hline Mean CRP mg/L (95\% CI) & $2.2(1.2-3.1)$ & $2.8(0.9-4.6)$ & $-0.6(-2.1-0.9)$ & 0.670 & $7.2(03.4-10.9)$ & $9.0(5.3-12.6)$ & $-1.8(-7.1-3.3)$ & 0.165 \\
\hline Mean ACPA U/mL (95\% CI) & $0.8(0.4-1.1)$ & $0.9(0.4-1.4)$ & $-0.1(-0.3-0.1)$ & 0.211 & $190.5(80.2-300.8)$ & $118(65.1-172.5)$ & $71.7(-23.9-167.3)$ & 0.136 \\
\hline Mean RF U/mL (95\% CI) & 15 & 15 & 0 & 1.000 & $213.8(86.9-340.7)$ & $166.7(73.3-259)$ & $47.7(-0.1-107.1)$ & 0.113 \\
\hline
\end{tabular}

*Paired Wilcoxon test. CI: confidence interval; RA: rheumatoid arthritis. Negative values denote an increase.

Table 4. Treatment effect association with biochemical parameters in patients with and without RA

\begin{tabular}{|c|c|c|c|c|c|}
\hline CRP & No-change / Increase & $\begin{array}{r}\text { Without RA } \\
9(42.9 \%)\end{array}$ & $\begin{array}{c}\text { RA } \\
18(62.1 \%)\end{array}$ & $\begin{array}{r}\text { Relative Risk } \\
0.4(0.1-1.4)\end{array}$ & $\begin{array}{c}p \\
0.145\end{array}$ \\
\hline & Reduction & $12(57.1 \%)$ & $11(37.9 \%)$ & & \\
\hline ACPA & No-change / Increase & $18(85.7 \%)$ & $13(44.8 \%)$ & $7.4(1.8-30.7)$ & 0.003 \\
\hline & Reduction & $3(14.3 \%)$ & $16(55.2 \%)$ & & \\
\hline $\mathrm{RF}$ & $\begin{array}{l}\text { No-change / Increase } \\
\text { Reduction }\end{array}$ & $\begin{array}{r}21(100.0 \%) \\
0(0.0 \%)\end{array}$ & $\begin{array}{l}12(41.4 \%) \\
17(58.6 \%)\end{array}$ & $0.4(0.2-0.6)$ & 0.001 \\
\hline
\end{tabular}

CI: confidence interval; RA: rheumatoid arthritis; CRP: C-reactive protein; ACPA; anti-citrullinated protein antibodies; RF: rheumatoid factor.

\section{Discussion}

This study aimed to compare the effects of NSPT on clinical parameters in patients with and without RA. An improvement in clinical periodontal parameters in both groups, reduction in ACPAs and RF, and increase in CRP in RA participants was observed at three months after the intervention. However, these findings should be interpreted with caution.

Clinical periodontal parameters improved in both groups after NSPT, and this finding was statistically significant within each group and in agreement with other studies ${ }^{22,27,28}$. Although participants without RA presented higher values in periodontal parameters at baseline as compared to RA participants and appeared to have had a more significant improvement, the relative magnitude of the change was similar between groups. Previous studies have found that periodontitis is more severe in RA patients ${ }^{10,29}$, but this was not the case of this study and therefore marks a difference. One possible explanation is the chronic use of potent anti-inflammatory medication such as DMARDs, which were exclusive in RA participants of this study. Results from animal studies showed reduced inflammation and bone loss in experimental periodontitis with the administration of chloroquine ${ }^{30}$. Recent studies in humans reported less progression in periodontal attachment loss in RA patients under DMARD medication ${ }^{31,32}$.

In addition, RA patients had access to managing protocols for their disease at their treating facility that included changes in daily habits and periodic visits to the doctor and dentist as opposed to patients without RA in this study. This could have influenced their periodontal condition ${ }^{33}$. In this matter, subgroup analysis of RA participants' clinical data showed a slightly better improvement in periodontal parameters in patients under biologic and nonbiologic DMARDs. Therefore, the possibility that DMARD medication slowed down the progression of periodontitis in RA participants is plausible and merits further studies in randomized clinical trials.

Previous studies have suggested beneficial effects of NSPT on biochemical markers of RA and eventual improvement of disease activity ${ }^{22}$. But changes in biochemical markers in RA participants may also be related to the altered immune and inflammatory reaction characteristic of the disease ${ }^{12,15}$. We found a greater decrease in ACPAs / RF and in contrast, an increase in CRP at three months after NSPT in RA participants but did not reach statistical significance. Furthermore, the response in ACPAs and RF in RA participants was towards reduction despite no change in RA medication during the study. In some patients,, the reduction of periodontal inflammation by NSPT may benefit biochemical serum markers. Although periodontal improvements were comparable in participants with and without RA, an improvement in the levels of ACPAs and RF in RA participants could be explained because they had increased levels before NSPT and, therefore, more room for reduction. 
Effects of nonsurgical periodontal therapy in patients with rheumatoid arthritis: a prospective before and after study.

Table 5. Change in periodontal parameters from baseline to 3 months according to medication in RA participants.

\begin{tabular}{|c|c|c|c|c|c|c|c|c|}
\hline \multirow{3}{*}{ Parameter } & \multicolumn{8}{|c|}{ Biologic DMARDs } \\
\hline & \multicolumn{3}{|c|}{ Yes } & \multirow[t]{2}{*}{$p^{*}$} & \multicolumn{3}{|c|}{ No } & \multirow[t]{2}{*}{$p^{*}$} \\
\hline & Baseline & 3 months & Change $(\Delta)$ & & Baseline & 3 months & Change $(\Delta)$ & \\
\hline Mean PAL $(95 \% \mathrm{CI})$ & $3.3(1.6-5.0)$ & $2.8(1.4-4.1)$ & $0.5(-0.3-1.4)$ & 0.180 & $2.8(2.2-3.3)$ & $2.5(2.0-3.0)$ & $0.3(0.1-0.4)$ & 0.002 \\
\hline \multirow[t]{4}{*}{ Mean PD $(95 \% \mathrm{CI})$} & $3.3(2.0-4.5)$ & $2.5(2.1-3.0)$ & $0.7(-0.2-1.6)$ & 0.109 & $2.9(2.5-3.3)$ & $2.3(2.2-2.5)$ & $0.5(0.3-0.8)$ & 0.002 \\
\hline & \multicolumn{8}{|c|}{ Non-biologic DMARDs } \\
\hline & \multicolumn{3}{|c|}{ Yes } & $p^{*}$ & \multicolumn{3}{|c|}{ No } & $p^{*}$ \\
\hline & Baseline & 3 months & Change $(\Delta)$ & & Baseline & 3 months & Change $(\Delta)$ & \\
\hline Mean PAL $(95 \% \mathrm{CI})$ & $2.9(2.3-3.5)$ & $2.5(1.9-3.0)$ & $0.4(0.1-0.6)$ & 0.003 & $3.1(2.1-4.1)$ & $2.9(1.8-3.9)$ & $0.3(-0.2-0.8)$ & 0.109 \\
\hline Mean PD $(95 \% \mathrm{CI})$ & $2.9(2.5-3.3)$ & $2.4(2.2-2.5)$ & $0.5(0.2-0.8)$ & 0.003 & $3.3(2.4-4.1)$ & $2.0(2.1-3.2)$ & $0.7(0.2-1.2)$ & 0.066 \\
\hline
\end{tabular}

*Paired Wilcoxon test. CI: confidence interval; RA: rheumatoid arthritis; PAL: periodontal attachment level; PD: probing depth; DMARD: disease-modifying antirheumatic drugs.

In contrast to the study by Cosgarea et al. ${ }^{22}$, CRP tended towards increase after NSPT. ACPAs and RF are highly variable parameters in RA and can show a great range of change after initiating treatment with DMARDs in patients with periodontitis ${ }^{34}$. On the other hand, CRP is an unspecific indicator of inflammation that can be elevated at 24-72 hours after severe tissue damage or infection ${ }^{35}$. Also, RA patients can have periods of disease remission/relapse and this way, the systemic inflammation will be altered increasing CRP levels ${ }^{36}$. The results agree with other studies ${ }^{22,27,37-39}$, but systematic reviews have shown no effect of NSPT on ACPAs and RF, consequently, producing contrasting conclusions ${ }^{23,40}$. It has been suggested that NSPT has systemic effects by reducing periodontal inflammatory sources ${ }^{21}$. However, the complex immune and systemic inflammatory response in the etiopathogenesis of RA makes this assumption more complicated despite the improvement in clinical parameters observed in our study. In addition, this study was not designed as a randomized clinical trial (RCT) and therefore, this reduction cannot be directly attributed to NSPT. It is more likely that the changes in biochemical parameters in patients with RA are to a certain extent the combined result of the activity of the disease, response to the medication used and NSPT, but this requires further studies.

Some studies have suggested an association between P. gingivalis and RA ${ }^{41}$. Additionally, periodontal intervention studies have reported an association between the reduction of $P$. gingivalis levels and improvement in RA disease activity ${ }^{42}$. Although NSPT resulted in the reduction of the total microbial counts, the counts of $P$. gingivalis increased at three months after therapy in our study. This may be related to the type of NSPT administered as a onesingle session of scaling and root planning may not be sufficient to suppress $P$. gingivalis in severe periodontitis cases effectively. In addition, subgingival samples were taken at three months from remaining periodontal pockets which could still be harboring high counts of the microorganism. It has been shown that $P$. gingivalis is prevalent in sites that do not improve after therapy ${ }^{43}$. However, no relation between $P$. gingivalis and the change in biochemical parameters of RA were observed in this study. Other researchers ${ }^{44,45}$, using molecular detection methods, found no significant association between $P$. gingivalis and RA and therefore, the relation between periodontitis and RA remains inconclusive due to high heterogeneity between studies.

The present study has the following shortcomings. First, the study was designed as a beforeand-after study since the purpose was to compare the effects of NSPT in patients with and without RA. It can be argued that only RCTs provide the only valid evidence. But the benefits of NSPT in restoring periodontal health have been extensively proven and thus it seemed more reasonable to administer the therapy to all participants ${ }^{46}$. However, sample size calculation and careful selection criteria and clinical measurement of important parameters allowed us to make valid real-world comparisons that are relevant for their periodontal and systemic condition. Second, follow-up time was only three months, and this was determined since participants were scheduled to receive only one session of NSPT and was the expected time to observe for initial clinical changes ${ }^{47}$. A more extended observation period would have only delayed additional periodontal treatment that participants needed for their condition. 


\section{Conclusions}

Nonsurgical periodontal therapy has similar improvements in periodontal parameters in patients with and without rheumatoid arthritis. In addition, NSPT may help reduce ACPAs and RF serum levels in patients with rheumatoid arthritis.

\section{References}

1. Kassebaum NJ, Bernabé E, Dahiya M, Bhandari B, Murray CJ, Marcenes W. Global burden of severe periodontitis in 1990-2010: a systematic review and meta-regression. J Dent Res. 2014; 93(11): 1045-1053. doi: 10.1177/0022034514552491. [PubMed]

2. Eke PI, Borgnakke WS, Genco RJ. Recent epidemiologic trends in periodontitis in the USA. Periodontol. 2000. 2020; 82 (1): 257-267. doi: 10.1111/prd.12323. [PubMed]

3. Ministerio de Salud y Protección Social. IV Estudio Nacional de Salud Bucal ENSAB IV. Situación en Salud Bucal. Ministerio de Salud y Protección Social; 2015.

4. Almutairi K, Nossent J, Preen D, Keen H, Inderjeeth C. The global prevalence of rheumatoid arthritis: a metaanalysis based on a systematic review. Rheumatol Int. 2021; 41 (5): 863-877. doi: 10.1007/s00296-020-047310. [PubMed]

5. Fernández-Ávila DG, Rincón-Riaño DN, Bernal-Macías S, Gutiérrez Dávila JM, Rosselli D. Prevalencia de la artritis reumatoide en Colombia según información del Sistema Integral de Información de la Protección Social. Rev Colomb Reumatol. 2019; 26: 83-87. doi: 10.1016/j.rcreue.2019.01.009.

6. Goh V, Hassan FW, Baharin B, Rosli TI. Impact of psychological states on periodontitis severity and oral health-related quality of life. J Oral Sci. 2021. doi: 10.2334/josnusd.21-0267.

7. Akram A, Georgiou P, Shi W, Proute MC, Serhiyenia T, Pradeep R, Kerolos ME, Kothur N, Khan S. Impact of Change in Lifestyle and Exercise on Cognitive Function in Patients With Rheumatoid Arthritis: A Systematic Review. Cureus. 2021; 13 (9): e18268. doi: 10.7759/cureus.18268. [PubMed]

8. Berthelot JM, Le Goff B. Rheumatoid arthritis and periodontal disease. Joint Bone Spine. 2010;77(6):537-41. doi: 10.1016/j.jbspin.2010.04.015. [PubMed]

9. Mikuls TR, Payne JB, Yu F, Thiele GM, Reynolds RJ, Cannon GW et al. Periodontitis and Porphyromonas gingivalis in patients with rheumatoid arthritis. Arthritis Rheumatol. 2014; 66 (5): 1090-100. doi: 10.1002/ art.38348. [PubMed]

10. Disale PR, Zope SA, Suragimath G, Varma AS, Pisal A. Prevalence and severity of periodontitis in patients with established rheumatoid arthritis and osteoarthritis. J Family Med Prim Care. 2020; 9 (6): 2919-2925. doi: 10.4103/jfmpc.jfmpc_398_20. [PubMed]

11. Brandl C, Bucci L, Schett G, Zaiss MM. Crossing the barriers: Revisiting the gut feeling in rheumatoid arthritis. Eur J Immunol. 2021; 51 (4): 798-810. doi: 10.1002/eji.202048876. [PubMed]

12. Mclnnes IB, Schett G. The pathogenesis of rheumatoid arthritis. N Engl J Med. 2011; 365(23): 2205-2219. doi: 10.1056/NEJMra1004965. [PubMed]

13. Potempa J, Mydel P, Koziel J. The case for periodontitis in the pathogenesis of rheumatoid arthritis. Nat Rev Rheumatol. 2017; 13 (10): 606-620. doi: 10.1038/nrrheum.2017.132. [PubMed]

14. Kondo N, Kuroda T, Kobayashi D. Cytokine Networks in the Pathogenesis of Rheumatoid Arthritis. Int J Mol Sci. 2021; 22 (20): 10922. doi: 10.3390/ijms222010922. [PubMed] 
Effects of nonsurgical periodontal therapy in patients with rheumatoid arthritis: a prospective before and after study.

15. Keirns BH, Lucas EA, Smith BJ. Phytochemicals affect T helper 17 and T regulatory cells and gut integrity: implications on the gut-bone axis. Nutr Res. 2020; 83: 30-48. doi: 10.1016/j.nutres.2020.08.006. [PubMed]

16. Yu HC, Lu MC. The roles of anti-citrullinated protein antibodies in the immunopathogenesis of rheumatoid arthritis. Ci Ji Yi Xue Za Zhi. 2019; 31 (1): 5-10. doi: 10.4103/tcmj.tcmj_116_18. [PubMed]

17. Jenning M, Marklein B, Ytterberg J, Zubarev RA, Joshua V, van Schaardenburg D et al. Bacterial citrullinated epitopes generated by Porphyromonas gingivalis infection-a missing link for ACPA production. Ann Rheum Dis. 2020; 79 (9): 1194-1202. doi: 10.1136/annrheumdis-2019-216919. [PubMed]

18. Hitchon CA, Chandad F, Ferucci ED, Willemze A, loan-Facsinay A, van der Woude D et al. Antibodies to porphyromonas gingivalis are associated with anticitrullinated protein antibodies in patients with rheumatoid arthritis and their relatives. J Rheumatol. 2010; 37 (6): 1105-1112. doi: 10.3899/jrheum.091323. [PubMed]

19. Oluwagbemigun K, Yucel-Lindberg T, Dietrich T, Tour G, Sherina N, Hansson M et al. A cross-sectional investigation into the association between Porphyromonas gingivalis and autoantibodies to citrullinated proteins in a German population. Ther Adv Musculoskelet Dis. 2019; 11: 1759720X19883152. doi: 10.1177/1759720X19883152.

20. Perricone C, Ceccarelli F, Saccucci M, Di Carlo G, Bogdanos DP, Lucchetti R, Pilloni A, Valesini G, Polimeni A, Conti F. Porphyromonas gingivalis and rheumatoid arthritis. Curr Opin Rheumatol. 2019; 31 (5): 517-524. doi: 10.1097/BOR.0000000000000638. [PubMed]

21. Gaudilliere DK, Culos A, Djebali K, Tsai AS, Ganio EA, Choi WM et al. Systemic Immunologic Consequences of Chronic Periodontitis. J Dent Res. 2019; 98 (9): 985-993. doi:10.1177/0022034519857714. [PubMed]

22. Cosgarea R, Tristiu R, Dumitru RB, Arweiler NB, Rednic S, Sirbu Cl et al. Effects of nonsurgical periodontal therapy on periodontal laboratory and clinical data as well as on disease activity in patients with rheumatoid arthritis. Clin Oral Investig. 2019; 23 (1): 141-151. doi: 10.1007/s00784-018-2420-3.

23. Kaur S, Bright R, Proudman SM, Bartold PM. Does periodontal treatment influence clinical and biochemical measures for rheumatoid arthritis? A systematic review and meta-analysis. Semin Arthritis Rheum. 2014; 44 (2): 113-122. doi: 10.1016/j.semarthrit.2014.04.009. [PubMed]

24. Monsarrat P, Fernandez de Grado G, Constantin A, Willmann C, Nabet C, Sixou M et al. The effect of periodontal treatment on patients with rheumatoid arthritis: The ESPERA randomised controlled trial. Joint Bone Spine. 2019; 86 (5): 600-609. doi: 10.1016/j.jbspin.2019.02.006. [PubMed]

25. Papapanou PN, Sanz M, Buduneli N, Dietrich T, Feres M, Fine DH et al. Periodontitis: Consensus report of Workgroup 2 of the 2017 World Workshop on the Classification of Periodontal and Peri-Implant Diseases and Conditions. J Clin Periodontol. 2018; 45 (Suppl 20): S162- S170. doi: 10.1111/jcpe.12946. [PubMed]

26. Botero JE, Contreras A, Lafaurie G, Jaramillo A, Betancourt M, Arce RM. Occurrence of periodontopathic and superinfecting bacteria in chronic and aggressive periodontitis subjects in a Colombian population. $\mathrm{J}$ Periodontol. 2007; 78 (4): 696-704. doi: 10.1902/jop.2007.060129. [PubMed]

27. Kaushal S, Singh AK, Lal N, Das SK, Mahdi AA. Effect of periodontal therapy on disease activity in patients of rheumatoid arthritis with chronic periodontitis. J Oral Biol Craniofac Res. 2019; 9 (2): 128-132. doi: 10.1016/j. jobcr.2019.02.002. [PubMed]

28. Buwembo W, Munabi IG, Kaddumukasa M, Kiryowa H, Mbabali M, Nankya E et al. Nonsurgical oral hygiene interventions on disease activity of Rheumatoid arthritis patients with periodontitis: A randomized controlled trial. J Dent Res Dent Clin Dent Prospects. 2020; 14 (1): 26-36. doi: 10.34172/joddd.2020.004. [PubMed] 
Effects of nonsurgical periodontal therapy in patients with rheumatoid arthritis: a prospective before and after study.

29. Tang Q, Fu H, Qin B, Hu Z, Liu Y, Liang Y et al. A Possible Link Between Rheumatoid Arthritis and Periodontitis: A Systematic Review and Meta-analysis. Int J Periodontics Restorative Dent. 2017; 37 (1): 79-86. doi: 10.11607/prd.2656. [PubMed]

30. He S, Zhou Q, Luo B, Chen B, Li L, Yan F. Chloroquine and 3-Methyladenine Attenuates Periodontal Inflammation and Bone Loss in Experimental Periodontitis. Inflammation. 2020; 43 (1): 220-230. doi: 10.1007/ s10753-019-01111-0. [PubMed]

31. Heredia-P AM, Lafaurie GI, Bautista-Molano W, Trujillo TG, Chalem-Choueka P, Bello-Gualtero JM et al. Predictive factors related to the progression of periodontal disease in patients with early rheumatoid arthritis: a cohort study. BMC Oral Health. 2019; 19 (1): 240. doi: 10.1186/s12903-019-0939-6. [PubMed]

32. Punceviciene E, Rovas A, Puriene A, Stuopelyte K, Vitkus D, Jarmalaite S, Butrimiene I. Investigating the relationship between the severity of periodontitis and rheumatoid arthritis: a cross-sectional study. Clin Rheumatol. 2021; 40(8):3153-3160. doi: 10.1007/s10067-021-05661-3. [PubMed]

33. Pisano GMM, González PA. Modifying habits and treatment adherence, essential for controlling the chronic disease. Enferm Clin. 2014; 24(1): 59-66. DOI: 10.1016/j.enfcli.2013.10.006. [PubMed]

34. Tachibana M, Yonemoto Y, Okamura K, Suto T, Sakane H, Kaneko T et al. Does periodontitis affect the treatment response of biologics in the treatment of rheumatoid arthritis? Arthritis Res Ther. 2020; 22 (1): 178 doi: 10.1186/s13075-020-02269-x. [PubMed]

35. Sproston NR, Ashworth JJ. Role of C-Reactive Protein at Sites of Inflammation and Infection. Front Immunol. 2018; 139:754. doi: 10.3389/fimmu.2018.00754.

36. Ajeganova S, Huizinga T. Sustained remission in rheumatoid arthritis: latest evidence and clinical considerations. Ther Adv Musculoskelet Dis. 2017; 9 (10): 249-262. doi: 10.1177/1759720X17720366. [PubMed]

37. Yang NY, Wang CY, Chyuan IT, Wu KJ, Tu YK, Chang CW et al. Significant association of rheumatoid arthritis-related inflammatory markers with nonsurgical periodontal therapy. J Formos Med Assoc. 2018; 117 (11): 1003-1010. doi: 10.1016/j.jfma.2017.11.006. [PubMed]

38. Nguyen VB, Nguyen TT, Huynh NC, Nguyen KD, Le TA, Hoang HT. Effects of nonsurgical periodontal treatment in rheumatoid arthritis patients: A randomized clinical trial. Dent Med Probl. 2021; 58 (1): 97-105. doi: 10.17219/dmp/131266. [PubMed]

39. de Smit MJ, Westra J, Posthumus MD, Springer G, van Winkelhoff AJ, Vissink A et al. Effect of AntiRheumatic Treatment on the Periodontal Condition of Rheumatoid Arthritis Patients. Int J Environ Res Public Health. 2021; 18 (5): 2529. doi: 10.3390/ijerph18052529. [PubMed]

40. Sun J, Zheng Y, Bian X, Ge H, Wang J, Zhang Z. Nonsurgical periodontal treatment improves rheumatoid arthritis disease activity: a meta-analysis. Clin Oral Investig. 2021; 25(8):4975-4985 doi: 10.1007/s00784-02103807-w.

41. Sakkas LI, Bogdanos DP, Katsiari C, Platsoucas CD. Anti-citrullinated peptides as autoantigens in rheumatoid arthritis-relevance to treatment. Autoimmun Rev. 2014; 13 (11): 1114-1120. doi: 10.1016/j. autrev.2014.08.012. [PubMed]

42. Moura MF, Cota LOM, Silva TA, Cortelli SC, Ferreira GA, López MM et al. Clinical and microbiological effects of nonsurgical periodontal treatment in individuals with rheumatoid arthritis: a controlled clinical trial. Odontology. 2021; 109 (2): 484-493. doi: 10.1007/s10266-020-00566-0. [PubMed]

43. Socransky SS, Haffajee AD. Dental biofilms: difficult therapeutic targets. Periodontol 2000. 2002; 28: $12-55$. doi: 10.1034/j.1600-0757.2002.280102.x. [PubMed] 
44. Lee JY, Choi IA, Kim JH, Kim KH, Lee EY, Lee EB, Lee YM, Song YW. Association between antiPorphyromonas gingivalis or anti-a-enolase antibody and severity of periodontitis or rheumatoid arthritis (RA) disease activity in RA. BMC Musculoskelet Disord. 2015; 12(16): 190. doi: 10.1186/s12891-015-0647-6.

45. Reichert S, Schlumberger W, Dähnrich C, Hornig N, Altermann W, Schaller HG, et al. Association of levels of antibodies against citrullinated cyclic peptides and citrullinated aa-enolase in chronic and aggressive periodontitis as a risk factor of Rheumatoid arthritis: A case control study. J Transl Med. 2015; 13 (1): 1-10. doi: 10.1186/s12967-015-0625-7. [PubMed]

46. Smiley CJ, Tracy SL, Abt E, Michalowicz BS, John MT, Gunsolley J et al. Evidence-based clinical practice guideline on the nonsurgical treatment of chronic periodontitis by means of scaling and root planing with or without adjuncts. J Am Dent Assoc. 2015; 146 (7): 525-35. doi: 10.1016/j.adaj.2015.01.026. [PubMed]

47. Claffey N. Decision making in periodontal therapy. The re-evaluation. J Clin Periodontol. 1991; 18 (6): $384-$ 389. doi: 10.1111/j.1600-051x.1991.tb02305.x. [PubMed] 